\author{
Jurnal Komteklnfo ( Komputer Teknologi Informasi ) \\ e-ISSN 2502-8758 || p-ISSN 2356-0010 \\ Vol : 6 || No : 1 || 2019 Hal 106-110 \\ http://lppm.upiyptk.ac.id/ojsupi/index.php/KOMTEKINFO
}

\title{
Web-Based Expert System to Diagnose Gastroenteritis in Children in Pariaman District Hospital using the Forward Chaining Method
}

\author{
Vicky Ariandi ${ }^{1} \mathrm{Hezy}$ Kurnia ${ }^{2}$ Aulia Fitrul Hadi ${ }^{3}$ \\ Universitas Putra Indonesia "YPTK" Padang \\ E-mail:vicky_ariandi@upiyptk.ac.id,
}

\begin{abstract}
Gastroenteritis is a digestive system disorder in the form of inflammation of the digestive system involving the stomach and small intestine. Gastroenteritis is usually called a stomach bug, gastro, or stomach virus. Although it has no connection with influenza, it is often referred to as stomach flu. Gastroenteritis is the most common digestive problem in children. Severe gastroenteritis will cause dehydration and electrolyte imbalance, this is caused by body fluids lost through diarrhea or vomiting. This system is a prototype and made as simple as possible, so that users can easily use it and redesign this expert system for other types. Because Because there are still many parents who do not know the symptoms of a disease. So an expert system was made that could diagnose early in gastroenteritis. By using a web-based forward chaining method, using this expert system, Gastroenteritis can be identified by looking at symptoms that can explain and describe whether a child is suspected of having a Gastroenteritis.

Keywords: Expert System, Web, Forward Chaining, Gastroenteritis
\end{abstract}

\section{Introduction}

Recent technological advances have had their own influence on the development of several fields such as agriculture, economics, education, government, health, and medicine. The effect can be seen in software. One of them is artificial intelligence[1]. Artificial intelligence has several branches that are more specific, including expert systems. Technology itself is now developing, not only as a practical science on technical matters, but has developed into one of the foundations of scientific knowledge at large. This is indicated by the many fields of science that are based on technology. Expert System is a system that seeks to adopt human knowledge into computers that are designed to model the ability to solve problems like an expert. With this expert system, ordinary people can either solve their problems or just look for quality information that can only be obtained with the help of experts in their fields. . This Expert System will also be able to assist the activities of experts as experienced assistants and have assistants who are experienced and have the required knowledge[2].

Forward chaining can also be called continuous trace or search driven data (data driven search). So the search starts from the premises or information input (if) first then goes to the conclusion or derived information (then). Forward Chaining means using a set of conditions-action rules. In this method, data is used to determine which rules to run or by adding data to working memory for processing to find an outcome. Gastroenteritis is an infection of the stomach and intestines caused by several types of viruses and bacteria. This condition is also known as stomach flu or stomach flu[3].

Gastroenteritis can cause nausea, vomiting, diarrhea, stomach cramps, or sometimes fever in the sufferer. Gastroenteritis can spread through close contact with an infected person or through food or drink that has been contaminated with a virus. This infection easily spreads in closed public facilities, such as in classrooms, child care areas, or public treatment rooms. Influenza of the stomach can occur in adults, children, to the elderly. However, due to differences in the immune system, children and the elderly tend to be more vulnerable to infection with bacteria that cause stomach flu. According to page seattlemamadoc.seattlechildrens.org, one of the symptoms of your child contracting this disease is diarrhea. However, if the symptoms are not accompanied by vomiting, then your child may only experience normal diarrhea. Vomiting - a symptom of gastroenteritis is if vomiting occurs for approximately 24 hours. Although this disease can also affect adults, symptoms of severe vomiting are shown by children who have the disease[4]. 


\section{Literature Review}

Software is a computer program associated with software documentation such as documentation of requirements, design models, and ways of use (user manual). A computer program without being associated with the documentation cannot be called software. A software is also often called a software system. The system means a collection of components that are interrelated and have one goal to be achieved. Software system means a system that has components in the form of software that has a relationship with each other to meet customer needs (customer). A customer is a person or organization that orders or purchases software from a software developer or it can be assumed that a customer is a person or organization who voluntarily spends money to order or buy software. Users or users of software are people who have an interest in using or using software to facilitate their work [5].

\subsection{Expert Systems}

The expert system is a branch of Artificial Intelligence (AI) which was developed in mid-1960. Expert system comes from the term knowledge-based expert system, which is a system that uses human knowledge where the knowledge is entered into a computer and then used to solve problems that usually require expertise or human expertise [6].

The expert system has 4 forms, namely: [7]

1. 1. Stand alone. This type of expert system is a stand-alone software that is not combined with other software.

2. 2. Combined, this type of expert system is a part of the program contained in an algorithm (conventional), or is a program where it calls another suburtin algorithm (conventional).

3. 3. Connecting to other software. This form is usually a system that connects to a particular program package, for example with a DBMS (Database Management System).

4. 4. Dedicated system. Expert system is part of a special computer that is connected with a particular function. For example an expert system used to help analyze radar data.

\subsection{Forward Chaining}

Forward chaining is a method of tracking forward which begins with the facts given by the user. Then a search is made on the knowledge base and then the search rules are in accordance with the facts. After that the hypothesis is carried out to obtain conclusions [8]. The forward chaining process can be seen in Figure 2.3 below::

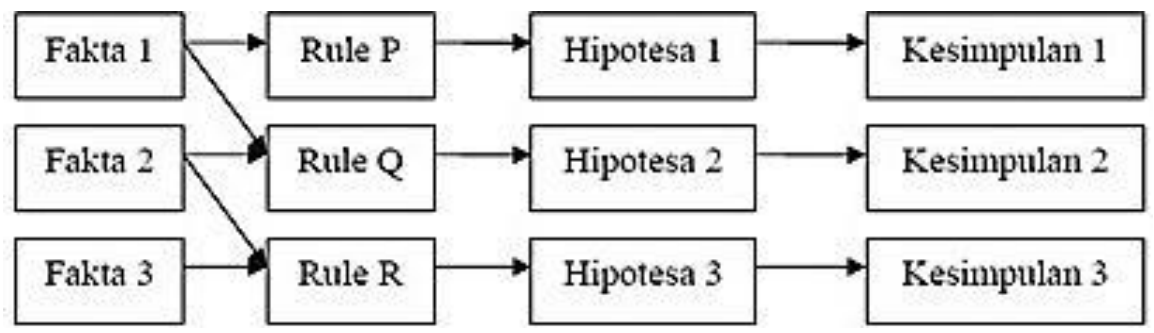

Picture 1: Proses Forward Chaining 


\section{Research Method}

The meaning of research is simply how to know something done in a certain way with a systematic procedure. Then the authors form the research framework as follows:

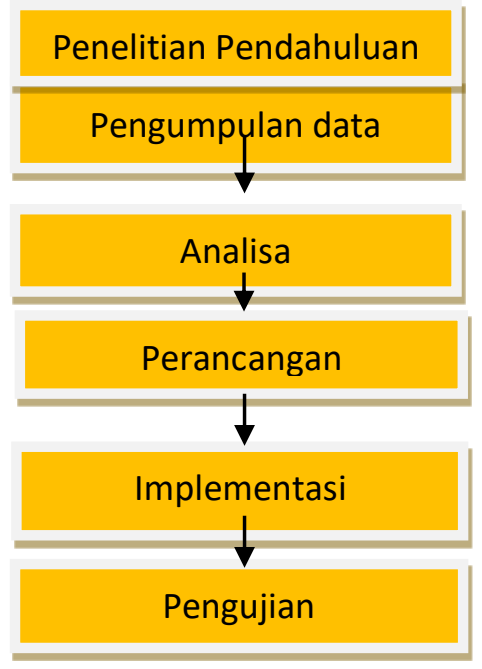

Picture 2 : Research Framework

\section{Analysis And Result}

\subsection{Decision Analysis}

The tracking method used in building a system for diagnosing diarrheal disease in children is forward chaining. The search starts from the premises or information input (if) first then goes to the conclusion or derived information (then). Forward Chaining means using a set of conditionsaction rules. The use of decision tree diagrams makes it easier to compile a knowledge base and rules and determine the certainty of diagnoses of gastroenteritis.

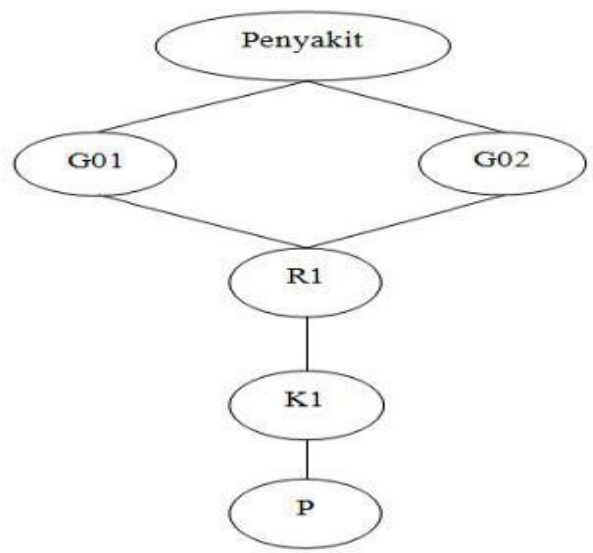

Picture 3 : Decision Tree 


\subsection{Result}

Testing and implementation of the system aims to see whether the system designed is in accordance with what is desired or not, after testing and implementation, the quality of a system will be seen. The program display is a sub-chapter that explains about the process of commencement until the program is finished executing, the points in this sub-chapter will explain about how a form is executed and what functions are contained in that form
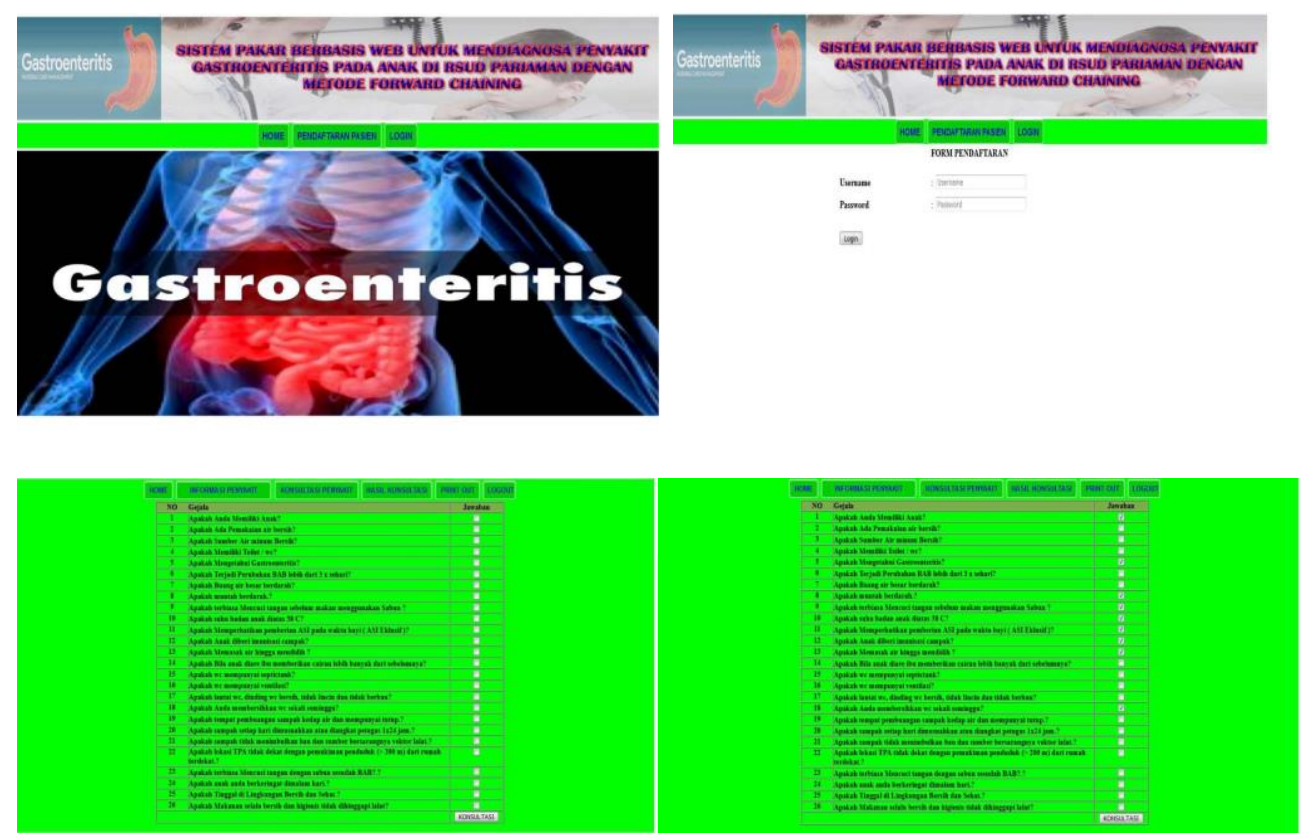

\section{Display of Consultation Results}

Picture 4. Application Review

Consultation results page contains information on the percentage of similarity of each disease symptom. Display The results of the consultation can be seen in the following figure:

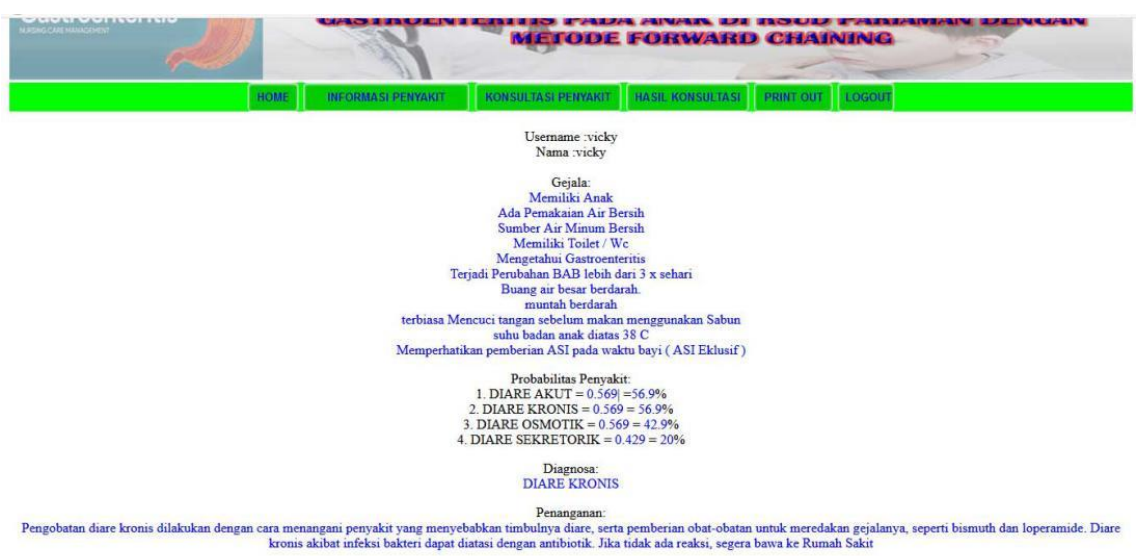

Gambar 4.5 Tampilan Hasil Konsultasi 


\section{Conclusion}

From the description of the problem above, and based on the analysis of the existing chapters, the following conclusions can be drawn:

1. The design of an expert system can make it easier to diagnose the symptoms of gastroenteritis, from tracing the symptoms that are felt to the diagnosis results from the symptoms based on the facts that happened before.

2. Expert system with forward chaining can provide a solution or way of handling gastroenteritis so that it can help the effectiveness of time and cost of the user in tackling the illness.

3. This expert system tracing using the method of forward chaining can produce gastroenteritis treatment solutions that are felt or suffered by children.

From the above studies the authors expect further research, because there are some shortcomings in the application and there are still many that have not been discussed because of the time constraints and limitations of the author in compiling this scientific work.

\section{Referensi}

[1] Galuh Gupita, Budi Harijanto, Yuri Ariyanto. "Pengembangan Sistem Pakar Pendeteksi Penyakit Pada Kucing Dengan Metode Case Based Reasoning Dan Certainty Factor Berbasis Android

." Jurnal Informatika Polinema (JIP) . (2017)

[2]Juansyah, Andi. "Pembangunan Aplikasi Child Tracker Berbasis Assisted-Global Positioning System (A-GPS) Dengan Platform Android." (2016).

[3] Kusuma, Diki Andita, and Chairani Chairani. "Rancang Bangun Sistem Pakar Pendiagnosa Penyakit Paru-Paru Menggunakan Metode Case Based Reasoning." Jurnal Infotel 6.2 (2014): 57-62.

[4] Mubarok, Akhmad Husain. "Aplikasi Panduan Teknisi Berbasis Android Untuk Mempermudah Penanganan Troubleshooting Pada PT KAI (Persero) Daop 3 Cirebon." JURNAL ICT 13.1 (2016).

[5] Novaliendry, Dony. "Multimedia Pembelajaran Bahasa Mandarin dan Website Promosi." Jurnal Teknologi Informasi dan Pendidikan 3.1 (2011).

[6] Palabiran, Meides, Dedy Cahyadi, and Zainal Arifin. "Sistem Informasi Geografis Kuliner, Seni Dan Budaya Kota Balikpapan Berbasis Android." Jurnal Informatika Mulawarman (JIM) 10.1 (2016): 5457.

[7] Purwadi, Joko, and Rosa Delima. "Implementasi Case Based Reasoning Untuk Sistem Diagnosis Penyakit Anjing." Jurnal Informatika 7.2 (2011).

[8] Sovia, R., \& Hadi, A. F. (2019). Membandingkan Metode SAW Dan MFEP Dalam Penentuan Jurusan di Tingkat SLTA. Jurnal RESTI (Rekayasa Sistem dan Teknologi Informasi), 3(1), 59-65. 